Neurolmages
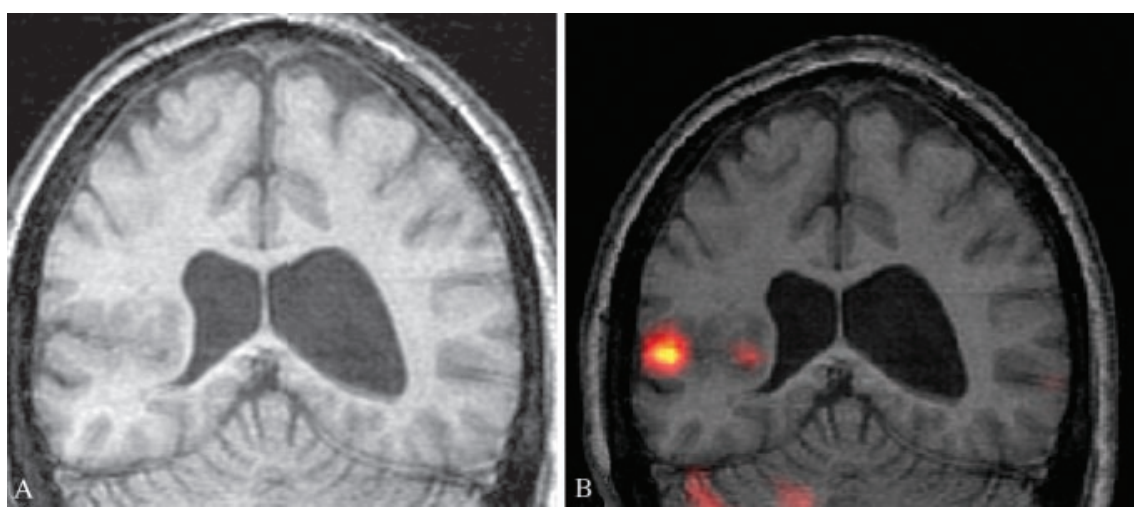

Figure 1. (A) Coronal MRI of right parietal area of heterotopic gray matter with compression of the atrium of the right lateral ventricle (arrow). (B) Coronal subtraction ictal SPECT coregistered on MRI (SISCOM) demonstrating a discrete region of ictal hyperperfusion within the heterotopia.

VIDEO

\section{SISCOM localization of a seizure focus within a heterotopia}

R. Zimmerman, $M D$; J. Sirven, $M D ;$ M. Roarke, $M D$; J. Drazkowski, MD; S. Larson, MD; S. Dixit, MD; and

C. Tollefson, Scottsdale, AZ and Las Vegas, NV

A man aged 38 years has a history of refractory epilepsy dating back to age 11 months. His daily seizures are complex partial (see video clip 1 on the Neurology Web site) with nonlocalizing motor components. The events have resulted in numerous bouts of status epilepticus despite having tried seven distinct antiepileptic drugs. An MRI (figure 1A) shows a right parietal area of heterotopic gray matter spanning from the wall of the lateral ventricle to the cortex. The patient underwent video EEG monitoring with subtraction ictal SPECT coregistered on MRI (SISCOM). SISCOM images revealed a discrete focus within the heterotopia (figure 1B). Intracranial EEG monitoring with a subdural grid and an eight-contact strip placed within a prominent anomalous posterior extension of the Sylvian fissure confirmed the SISCOM finding (figure 2). Resection of the epileptogenic tissue $(\sim 3 \mathrm{~cm})$ corresponding to the SISCOM finding resulted in complete seizure relief at current postoperative clinic visit (6 months).

Gray matter heterotopias often result in focal intractable seizures. Scalp EEGs can be lateralizing but are often nonlocalizing in these conditions. SISCOM may be particularly helpful in these lesions to help guide intracranial EEG coverage. SISCOM detection of a hyperperfusion focus is twice that of conventional SPECT (88\% vs 39\%). ${ }^{1}$

Additional material related to this article can be found on the Neurology Web site. Go to www.neurology.org and scroll down the Table of Contents for the June 22 issue to find the title link for this article.

Address correspondence and reprint requests to Dr. Joseph I. Sirven, Neurology/Epilepsy 5W, 5777 East Mayo Boulevard, Mayo Clinic Hospital, Phoenix, AZ 85054; e-mail: Sirven.Joseph@mayo.edu

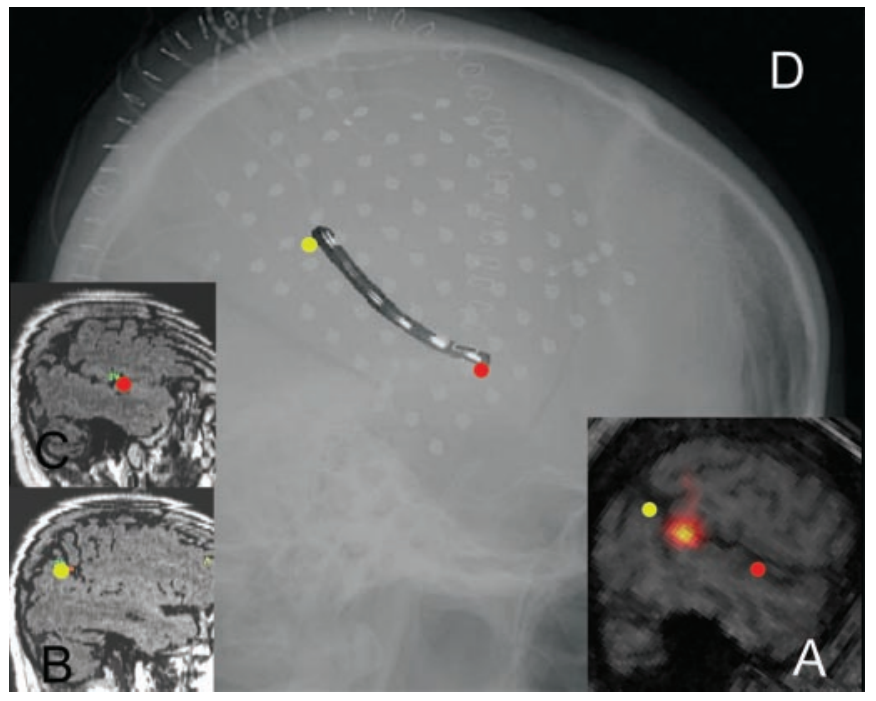

Figure 2. Intracranial EEG confirmation of SISCOM seizure localization. (A) Pre-operative saggital SISCOM with anterior (red) and posterior (yellow) extent of anomalous Sylvian fissure to be monitored within the heterotopia. (B, C) Intra-operative Stealth image guided placement of dual sided subdural strip electrode. (D) Post-implant lateral skull radiograph highlighting the location of the dual sided strip electrode within the heterotopia. Subdural grid electrodes placed on the convexity overlying the heterotopia are also seen.

1. O'Brien TJ, So EL, Mullan BP, et al. Subtraction ictal SPECT coregistered to MRI improves clinical usefulness of SPECT in localizing the surgical seizure focus. Neurology 1998;50:445-454. 


\section{Neurology}

\section{SISCOM localization of a seizure focus within a heterotopia \\ R. Zimmerman, J. Sirven, M. Roarke, et al. \\ Neurology 2004;62;2328 \\ DOI 10.1212/01.WNL.0000130787.25976.EE}

This information is current as of June 21, 2004

\section{Updated Information \&}

Services

Supplementary Material

References

Permissions \& Licensing

Reprints including high resolution figures, can be found at:

http://n.neurology.org/content/62/12/2328.full

Supplementary material can be found at:

http://n.neurology.org/content/suppl/2004/06/06/62.12.2328.DC1

This article cites 1 articles, 1 of which you can access for free at: http://n.neurology.org/content/62/12/2328.full\#ref-list-1

Information about reproducing this article in parts (figures,tables) or in its entirety can be found online at:

http://www.neurology.org/about/about_the_journal\#permissions

Information about ordering reprints can be found online:

http://n.neurology.org/subscribers/advertise

Neurology ${ }^{\circledR}$ is the official journal of the American Academy of Neurology. Published continuously since 1951, it is now a weekly with 48 issues per year. Copyright. All rights reserved. Print ISSN: 0028-3878. Online ISSN: 1526-632X.

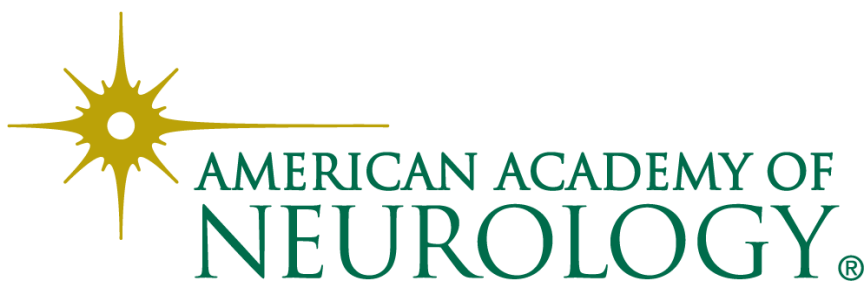

